\title{
An Examination of the Efficient Market Hypothesis: The Evidence from Practitioners of Money Management
}

\author{
Augustine C. Arize \\ Business Administration and Management Information Systems \\ College of Business and Entrepreneurship, Texas A\&M \\ Andreas C. Christofi \\ Chair, Economics, Finance, and Real Estate \\ Leon Hess Business School, Monmouth University
}

John Malindretos

Economics, Finance, and Global Business

Cotsakos College of Business, William Paterson University

Brian Maruffi
Entrepreneurship and Management
Syms School of Business, Yeshiva University

Moschos Scoullis

Economics and Finance

School of Business, Montclair State University

Received: Jan. 9, 2013

doi:10.5296/jmr.v5i3.3022
Accepted: April 3, 2013

Published: July 1, 2013

URL: http://dx.doi.org/10.5296/jmr.v5i3.3022 


\section{Abstract}

This research study examines practical money management to find out the goals of practitioners as well as techniques that enable them to manage money. We specifically examine whether practitioners follow either the informational efficiency or inefficiency approach to invest for their clients. We corroborate their answers with their perceptions of their own performance evaluations.

Keywords: Efficiency, fundamental analysis, technical analysis, practitioners of money management, evaluation of performance, January effect, market value to book value, PEG ratio, $\mathrm{P} / \mathrm{E}$ ratios 
There is an ongoing debate about whether markets are efficient. The proponents of the efficiency market hypothesis (EMH) believe that investors may not beat the average rate of return (ROR) such as the Standard and Poor's 500 stock index (S\&P 500).The efficiency camp thinks that information is disbursed extremely rapidly and that there are no lingering investments that can have extraordinary returns. Thus, the recommendation from that viewpoint would be to avoid attempting to surpass the ROR at a given risk. In other words, the efficiency camp would suggest investing in an index fund, since one cannot do better than the market return that the index fund replicates. Furthermore, there are greater fees involved with managing money actively.

The inefficiency viewpoint of the stock market argues that superior security analysis could lead to superior ROR at a given risk. This hypothesis states that past trends, patterns, and financial/economic information can induce superior returns; this viewpoint is called technical analysis.This approach also believes that adjustments do not occur at once, so that there do exist opportunities for above normal returns as prices adjust with delays in the spread of information. Thus, it behooves investors to pursue practical money management actively so they can beat the S\&P 500 or some other index.

There are numerous tests of efficiency. First, there are tests that use the filter rule, which says if a stock rises (falls) by $7 \%$, for example, from a certain price determined to be the regular price, then it continues to rise (fall).Evidence exists that there are excess profits to be obtained according to filter rules, although high transactions costs eliminate those profits (Sweeney, 1988).Second, there is a type of test that looks at whether earnings surprises induce prices to adjust instantaneously or to remain stable beyond the day of the earnings surprise announcement. Efficiency is supported if the adjustment is immediate whereas inefficiency is supported if the adjustment takes time. According to Jones, Rendleman, and Latane (1985), almost half of such price alterations took place three months after the announcement of the earnings surprise, a finding which supports informational inefficiency.

A third test of efficiency is the so-called January effect. The result of the aforementioned test is that an investor receives a lower ROR if he/she invests in January. The reason is because of tax selling, where massive selling at the end of the calendar year causes lower prices, followed by higher prices in January when many investors are buying (Branch, 1977).Fourth, researchers have considered price earnings $(\mathrm{P} / \mathrm{E})$ ratios compared to the growth potential of those stocks (the PEG ratios) and have found an inverse relationship between PEG ratios and RORs (Peters, 1991).This finding, of course, contradicts the efficiency view.

Fifth, researchers have looked at whether the size of a firm affects the ROR of its stock. If so, then inefficiency is supported because investors can enhance their RORs by investing in small market cap stocks (Reinganum, 1992). Researchers next examined neglected firms and discovered that there is a positive relationship between neglect and risk-adjusted RORs, thereby contradicting the notion of efficiency (Arbel \& Strebel, 1983).Finally, many people have given evidence of the positive correlation between risk-adjusted ROR and the book to market value ratio, which again supports informational inefficiency (Fama \& French, 1992). 
This study attempts to find out how practitioners of money management actually manage money. We emailed the enclosed questionnaire to 5000 money managers five times each. Out of the respondents, 570 use fundamental analysis and 432 use technical analysis (TA).Only 50 out of 820 respondents (6\%) espouse $\mathrm{EMH}$, or the efficiency view. Thus, the great majority of our respondents subscribes to the view that markets are inefficient and follows techniques consistent with this viewpoint, i.e., technical and fundamental analyses.

TA itself is another approach endorsing active money management and is one of the three key approaches to professional investment services. TA involves examining past trends and movements of stocks and markets and making choices about the future developments of individual firms and markets, thus contradicting the efficiency view by stating that investors can use public historical information to beat market averages. Thus, money managers (MMs) who espouse TA will invest aggressively to try to beat the indices. A slight majority of our respondents (52.6\%) use TA.

Fundamental analysis is an approach that examines economic, financial, political, social, and legal factors. It presumes that these factors exert a great influence on stock prices because said factors affect the ROR and an investment's risk. Its proponents feel that superior analysis by MMs will lead to higher RORs and overall better investments. Security analysis is valuable since it will attain the aforementioned, with the implication being that MMs should pursue active fundamental analysis in order to obtain better values and RORs. Fundamental analysis indirectly believes in informational inefficiency, e.g., if our money managers believe in the small cap effect then they should invest in small capitalized stocks, following their fundamental analysis.

We also wished to connect our respondents' viewpoints with belief in the effectiveness of their own performance, and so we asked our practitioners to rate their own individual performance. They rated themselves as good (56\%), excellent (37\%), and average (18\%); none answered that he/she is below average. From a casual observation, our respondents are biased. Only about $10 \%$ of the MMs beat the S\&P 500 in the short run and none of them beat the S\&P 500 over the long run. This important question compares the reality versus the perception: the perception was that $93 \%$ surpassed the ROR of the indices but the reality is that only a maximum of $10 \%$ surpassed the markets. The difference is a staggering $80 \%+$ differential between belief in surpassing the market averages from the actuality, which is a huge disconnect between the practice and the facts of practitioners of money management.

So far we have given evidence that practitioners fall into several camps, including one that disbelieves the EMH and a specific subgroup that disbelieves the weak form of the EMH. Nearly 53\% of this overall group of disbelievers in the EMH use diverse aspects of TA, believing that the use of historical and current market data can produce a better than average ROR.A larger group of such disbelievers, comprising 70\%, considers that fundamental analysis can lead to a higher ROR, so these practitioners pursue analysis of other economic factors that could lead them to surpass the market's ROR. Both of these groups disbelieve in the efficiency view of investors and money managers being unable to beat the market using public information. 
Another camp, making up only $6 \%$ of our respondents, believes in and practices the dictates of the EMH. Thus, we would expect such respondents to be sufficiently happy with a normal ROR by investing in an index fund and replicating the S\&P 500.

The fact that the practitioners of our study believe they can do better than the averages is corroborated by the responses about their performance. Only 18\% answered that they are average and 56\% rated themselves as good, so their self-ratings implied that their returns surpass the normal ROR.A full 37\% responded that they are excellent. Of course, the respondents answering either good or excellent definitely believe that they can do better than the averages. Thus, the great majority (93\%) of the money managers believe that the EMH does not apply and that they can do better than the market. There is a coincidence of beliefs in our respondents' answers and their basic approach toward managing money: since a strong majority of them (70\%) use fundamental analysis and 53\% use technical analysis, they say and believe that they can do better than the market averages.

\section{References}

Arbel, A., \& Strebel, P. (1983).Pay Attention to Neglected Firms. Journal of Portfolio Management, 9(2), 37-42. http://dx.doi.org/10.3905/jpm.1983.408901

Beard, C., \& Sias, R. (1997). Is There a Neglected Firm Effect? Financial Analysts Journal, 53(5), 19-23. http://dx.doi.org/10.2469/faj.v53.n5.2113

Branch, B.(1977)A Tax Loss Trading Rule. Journal of Business, 50(2), 198-207. http://dx.doi.org/10.1086/295930

Branch, B., \& Chang, K.C.(1985).Tax Loss Trading -- Is the Game Over or Have the Rules Changed? Financial Review, 20(1), 55-69. http://dx.doi.org/10.1111/j.1540-6288.1985.tb00164.x

Brown, G.(1999).Volatility, Sentiment, and Noise Traders. Financial Analysts Journal, 55(2), 82-90. http://dx.doi.org/10.2469/faj.v55.n2.2263

Clark, R.G., \& Statman, M.(1998).Bullish or Bearish? Financial Analysts Journal, 54(3), 63-72. http://dx.doi.org/10.2469/faj.v54.n3.2182

Cordell, D.M., Langdon, T.P., \& Lemoine, C.W. (2006).Bridging the Gap: Academic Research that is Relevant to Practitioners.Journal of Financial Service Professionals, 60(6), 72-78.

Cordell, D.M., Langdon, T.P., \& Lemoine, C.W. (2008). Academic Research that is Relevant to Financial Service Professionals. Journal of Financial Service Professionals, 62(6), 36-44.

Cordell, D.M., Langdon, T.P., \& Tacchino, K. (2010). Financial Planning Research: Articles that Practitioners Can Use. Journal of Financial Service Professionals, 64(6), 75-84.

Cordell, D.M., Langdon, T.P., \& Lemoine, C.W. (2012). Academic Research that Practitioners Can Use. Journal of Financial Service Professionals, 66(2), 88-96. 
Evensky, H.(2004). It's Time for a Change: Portfolio Design and Implementation. Journal of Financial Service Professionals, 58(5), 23-26.

Fama, E.F.(1970).Efficient Capital Markets: A Review of Theory and Empirical Work. Journal of Finance, 25(2), 383-417. http://dx.doi.org/10.2307/2325486

Fama, E.F.(1991).Efficient Capital Markets: II. Journal of Finance, 46(5), 1575-1617. http://dx.doi.org/10.1111/j.1540-6261.1991.tb04636.x

Fama, E.F., \& French, K.R. (1992).The Cross Section of Expected Stock Returns. Journal of Finance, 47(2), 427-465. http://dx.doi.org/10.1111/j.1540-6261.1992.tb04398.x

Jensen, G.R., Johnson, R.R., \& Mercer, J.M.(1997).New Evidence on Size and Price to Book Effects in Stock Returns.Financial Analysts Journal, 53(6), 34-42. http://dx.doi.org/10.2469/faj.v53.n6.2128

Jones, C.P., Rendleman, R.J., \& Latane, H.A.(1985).Earnings Announcements: Pre- and Post Responses.Journal of Portfolio Management, 11(3), 28-32. http://dx.doi.org/10.3905/jpm.1985.409002

Keim, D.B.(1986).The CAPM and Equity Return Regularities. Financial Analysts Journal, 42(3), 19-34. http://dx.doi.org/10.2469/faj.v42.n3.19

Levy, R.A. (1966). Conceptual Foundations of Technical Analysis. Financial Analysts Journal, 22(4), 83. http://dx.doi.org/10.2469/faj.v22.n4.83

Lo, A.W., Mamaysky, H., \& Wang, J. (2000). Foundations of Technical Analysis: Computational Algorithms, Statistical Inference, and Empirical Implementation. Journal of Finance, 55(4), 1705-1770. http://dx.doi.org/10.1111/0022-1082.00265

Nawrocki, D.(1997).Capital Market Theory: Is It Relevant to Practitioners? Journal of Financial Planning, 10(5), 97-102.

Olsen, R.A. (1998). Behavioral Finance and Its Implications for Stock Price Volatility.Financial Analysts Journal, 54(2), 10-18. http://dx.doi.org/10.2469/faj.v54.n2.2161

Peters, D.J.(1991). Valuing a Growth Stock. Journal of Portfolio Management, 17(3), 49-51. http://dx.doi.org/10.3905/jpm.1991.409339

Rendleman, R.J., Jones, C.P., \& Latane, H.A.(1982). Empirical Anomalies Based on Unexpected Earnings and the Importance of Risk Adjustments. Journal of Financial Economics, 10(3), 269-287. http://dx.doi.org/10.1016/0304-405X(82)90003-4

Reinganum, M.R.(1992). A Revival of the Small-Firm Effect. Journal of Portfolio Management, 18(3), 55-62. http://dx.doi.org/10.3905/jpm.1992.409404

Rosenberg, B., Reid, K., \& Lanstein, R. (1985). Persuasive Evidence of Market Inefficiency. Journal of Portfolio Management, 11(3), 9-17. http://dx.doi.org/10.3905/jpm.1985.409007 


\section{Macrothink}

Journal of Management Research

ISSN 1941-899X 2013, Vol. 5, No. 3

Scott, J., Stumpp, M., \& Xu, P. (1999). Behavioral Bias, Valuation, and Active Management.Financial Analysts

http://dx.doi.org/10.2469/faj.v55.n4.2284

Shefrin, H. (2001). Behavioral Corporate Finance. Journal of Applied Corporate Finance, 14(3), 113-124. http://dx.doi.org/10.1111/j.1745-6622.2001.tb00443.x

Shefrin, H. (1999). Beyond Greed and Fear: Understanding Behavioral Finance and the Psychology of Investing. Boston: Harvard Business School Press.

\section{APPENDIX}

A. How would you rank the approaches of investments you follow?

1. Efficiency Market Hypothesis

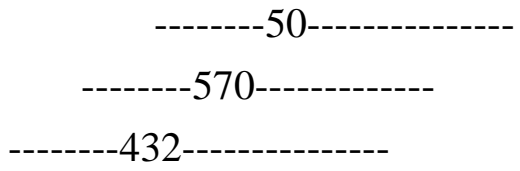

B. How would you rate your performance, i.e., the rate of return adjusted for risk such as in a Sharpe or Treynor measure?

1. Excellent

$265-$

2. Good

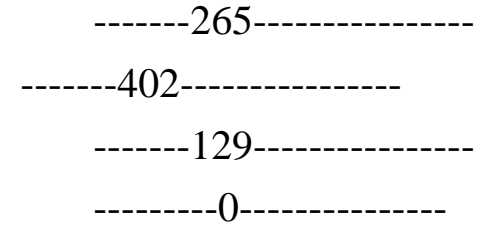

3. Average

4. Below average 